\title{
EFFECT OF WORK ENVIRONMENT AND ORGANIZATIONAL CULTURE ON EMPLOYEE PERFORMANCE WITH MEDIATED WORK MOTIVATION (Study on Operational Field Employee of PT Bank Pembangunan Daerah Provinsi Jawa Timur Tbk Sidoarjo Branch)
}

\author{
Adiwiratna Briandana \\ Ganefanto Rachmat \\ Faculty of Economics and \\ Business, University of \\ Brawijaya \\ Malang, Indonesia \\ adiwbgr@gmail.com

\section{Noermijati} \\ Faculty of Economics and \\ Business, University of \\ Brawijaya \\ Malang, Indonesia \\ Sudjatno \\ Faculty of Economics and \\ Business, University of \\ Brawijaya \\ Malang, Indonesia
}

\begin{abstract}
This research aims to examine and analyze the effect of the work environment and organizational culture on the operational field employee performance of PT Bank Pembangunan Daerah Provinsi Jawa Timur Tbk Sidoarjo Branch with mediated work motivation. The population in this research was 134 employees. Data analysis in this research is the SEM using sofware PLS. The results of this research show that influential work environment significantly on the employee performance, organizational culture affect significantly on the employee performance, work environment affect significantly on the work motivation, organizational culture affect significantly on the work motivation, work motivation affect significantly on the employee performance. Motivation work also roles as a partial mediation from the effect of work environment on performance of employees and the effect of organizational culture on performance of employees.
\end{abstract}

Keywords: Work Environment, Organizational Culture, Work Motivation, and Employee Performance

\section{INTRODUCTION}

Each company will make efforts in improving the performance of both company performance and employee performance. The effort began with the making change of all aspects that are owned by the company. However, companies also need to pay attention to other factors that can affect the company's efforts to improve performance, especially employee performance, namely motivation, insight, skills, work relations between employees, work environment, organizational culture, and other factors. Mahmudi (2010) explained that factors that affect employee performance are Personal / Individual factors (knowledge, motivation, and skills), leadership factors, team factors (cohesiveness and closeness of team members), system factors (performance culture in organizations), and contextual factors (pressure and changes in the external and internal environment).

Bambang (1991) explains that the work environment is one of the factors that influence the performance of an employee. An employee who works in a work environment that supports him to work optimally will produce good performance. Conversely, if an employee works in an inadequate work environment and does not support working 
optimally, the employee will become lazy, tired so that performance the employee will be low. Based on this, the influence of the work environment on employee performance can be strengthened by some of the results of previous research. Research conducted by Malik et al. (2011), the results showed that the influential working environment significantly on the employee performance. Furthermore, the research conducted by Nguyen et al. (2014), it was found that the influential working environment significantly on the employee performance. Similar research was also conducted by Jayaweera (2015), the results of the research showed that the work environment had a significant effect on the work performance of hotel employees.

Furthermore, the factors that affect the company's efforts in improving the performance of employees is the organizational culture. Organizational culture has full strength, affects on individuals and performance even in the work environment (Kotter and Heskett, 1992). Basically, building and creating an organizational culture, companies need to pay attention to organizational culture characteristics including innovation and risk taking, attention to details, results orientation, people orientation, team orientation, aggressiveness, and stability (Robbins, 2012). Based on this, then to see the influence of organizational culture on employee performance can be strengthened by the results of previous reseacrh. Research conducted by Murugan (2009), where the results of the research show that organizational culture has a significant effect on employee performance. Subsequent research by Shahzad (2014), the results of the reseacrh show that organizational culture has a significant effect on employee performance. Research conducted by Wahyuni (2015), the results of the research show that organizational culture has a positive effect on employee performance.

\section{LITERATURE REVIEW}

\section{Work Environment}

According to Sedarmayanti (2001), states that generally, the type of work environment is divided into 2 namely physical work environment is a physical work environment is all physical conditions that are around the workplace that can affect employees directly or indirectly such as temperature, noise, lighting, air quality, space, security, and cleanliness, while the non-physical work environment is all the circumstances that occur relating to work relationships, both relationships with superiors and relationships with subordinates of fellow colleagues, or relationships with subordinates.

\section{Organizational Culture}

Robbins (2002) defines organizational culture as a shared perception shared by organizational members, a system of shared meaning. Organizational culture is a value system held and carried out by members of the organization, so that such things can distinguish the organization from other organizations. The value system is built by seven characteristics, namely Innovation and risk taking (Innovation and Risk Taking) is the level where employees are encouraged to be innovative and take risks, Attention to Details is the level at which employees are expected to show precision, analysis, and attention to detail, Outcome orientation (outcome orientation) is the level at which management focuses on results, not on the techniques and processes used to achieve results, People Orientation is a level which management decisions consider the impact of results on people in the organization, Team Orientation is a level where work activities are organized around teams, not individuals, Aggressiveness is a level which people (members of an organization) have an aggressive and competitive nature rather 
than relaxed, and stability (Stability) is a level which the organization's activities emphasize the status quo being maintained rather than growth (Robbins, 2012).

\section{Work Motivation}

Two factors cause satisfaction or dissatisfaction according to Herzberg, namely maintenance factors and motivational factors. Maintenance factors are also called dissatisfiers, hygiene factors, and extrinsic factors. Meanwhile, motivational factors are also called satisfiers, motivators, and intrinsic factors. Motivation factors or intrinsic factors are a driving factor for someone to achieve, this factor comes from within a person. factors that lead to job satisfaction consist of factors related to the content of work, including responsibility, advancement, achievement, recognition, work it self, personal growth. Meanwhile, Hygiene factors or extrinsic factors, which are factors associated with efforts to maintain the existence of employees. This factor consists of company policy and administration, wages, status, job security, working conditions, interpersonal relationships with colleagues, interpersonal relationships with supervisors, and quality of supervision (Noermijati, 2013).

\section{Employee Performance}

According to Fahmi (2010) states that performance is the result obtained by an organization both the organization is profit oriented and non profit oriented which is produced during a period of time. The results obtained by an organization can be seen through a performance appraisal process. According to Noermijati (2013) that work assessment is a way to assess employees in accorandce with activities in carrying out their responsibilities or in other words is a process to assess employee performance in carrying out tasks in their respective fields of work. Through performance appraisal, management can evaluate work results so that they can know the elements of the work being assessed and how employees who perform well in their work, so that each element of the work that is assessed can run well. Robbins (2006) proposes three criteria that can be used to measure performance namely Work quality is quality that must be produced in work, quantity is the amount that must be completed and accomplished in work, attitude is evaluative statement both pleasant and unpleasant towards objects, individuals and event.

\section{HYPOTHESIS}

According to Ilgen and Favero (1985), the work environment is one of the factors that influence employee performance. Carson, et al. (1991) believe that the work environment has an impact on employee behavior and work outcomes. The work environment in question is the realization of a comfortable, competitive work atmosphere, and the existence of adequate work facilities and infrastructure. An adequate work environment will be able to form a more effective and efficient performance. The relationship caused by the work environment has a positive impact on employee performance. Deeper, the relationship can be seen based on some results of previous studies. Some previous research findings show that the work environment has a significant effect on employee performance (Malik, et al., 2011, Nguyen, et al., 2014, Jayaweera, 2015, Nurjanah, et al., 2014). Based on the study above, hypotheses can be arranged as follows:

$H_{1}$. Work Environment affect positive and significant effect on employee performance. 
In fact, it can be seen that according to a company there are rules and values applied by the company to employees in order to maintain harmony both for the long term and the short term. Organizational culture has full strength, influences individuals and performance even on the work environment (Kolter and Heskett, 1992). This concept shows that organizational culture has a positive impact on employee performance. deeper, the relationship between organizational culture and employee performance can be seen from the results of several previous reseacrh. Some of the results of previous research indicate that organizational culture has a significant effect on employee performance (Murugan, 2009, Shahzad, 2014, Wahyuni, 2015, Nurdin, et al., 2016). Based on the explanation above, the hypothesis can be arranged as follows:

\section{$H_{2}$. Organizational culture affect positive and significant on employee performance.}

According to the opinions of Isaac and tanjung cited by Riansari (2013) concerning the benefits of the work environment is creating a work of passion, so that productivity and work achievement increases. Meanwhile, the benefits obtained from working with motivated people are work completed according to the correct standards and on a specified time scale. This concept will explain that the work environment will has a positive impact on employee motivation. This is supported by several previous research, namely the results of several research show that the work environment has a positive and significant influence on work motivation (Martin ,1996, Noor, 2014, Sanny, et al., 2012). Based on the empirical study above, the hypothesis can be arranged as follows:

\section{$H_{3}$. Work Environment affect positive and significant on work motivation.}

According to Fahmi (2013) organizational culture is a habit that has lasted a long time and is used and applied in the life of work activities as one of the drivers to improve the quality of work of employees and company managers. One of the drivers to improve the quality of work of employees is by encouraging employee work motivation. Deeper, the relationship between corporate culture to work motivation can be seen from the results of research that has been done before. The results of empirical studies by several previous research indicate that shows that organizational culture has a positive and significant effect on work motivation (Taslim, 2011, Koesmono, 2005, Ernanto, et al., 2015). Based on the empirical study above, the hypothesis can be arranged as follows:

\section{$\mathrm{H}_{4}$. Organizational culture affect positive and significant on the work motivation.}

Factors that influence performance according to Mahmudi (2010), one of them mentioned is motivation. This is because motivation and performance have strong relationships. Strong relationships can be seen from previous research where the results of the research indicate that motivation influences performance. According to some results of the research, the results showed that work motivation had a significant effect on employee performance (Shafighi, et al., 2013, Zameer, 2014; Supartini, 2017, Ardiaz, et al., 2017, Prabowo, et al., 2018). Based on the empirical study above, the hypothesis can be arranged as follows:

\section{$H_{5}$. Work motivation affect positive and significant on the employee performance.}

Based on the results of Martin (1996), Noor (2014), and Sanny, et al. (2012) then found a significant influence between the work environment on work motivation, and the research conducted by Malik, et al. (2011), Nguyen, et al. (2014), Jayaweera (2015), Nurjanah, et al. (2014) shows the results that the work environment has a positive effect on employee performance. Therefore hypotheses can be arranged as follows: 
$H_{6}$. Work motivation mediates the effect of the work environment on employee performance.

Based on the results of the research by Murugan (2009), Shahzad (2014), Wahyuni (2015), Endrias (2014), it was found that there was a significant effect between organizational culture on employee performance and the results of research conducted by Taslim (2011), Koesmono (2005), Ernanto, et al. (2015) that there is a significant influence between organizational culture on work motivation. Therefore hypotheses can be arranged as follows:

$\mathrm{H}_{7}$. Work motivation mediates the effect of organizational culture on employee performance.

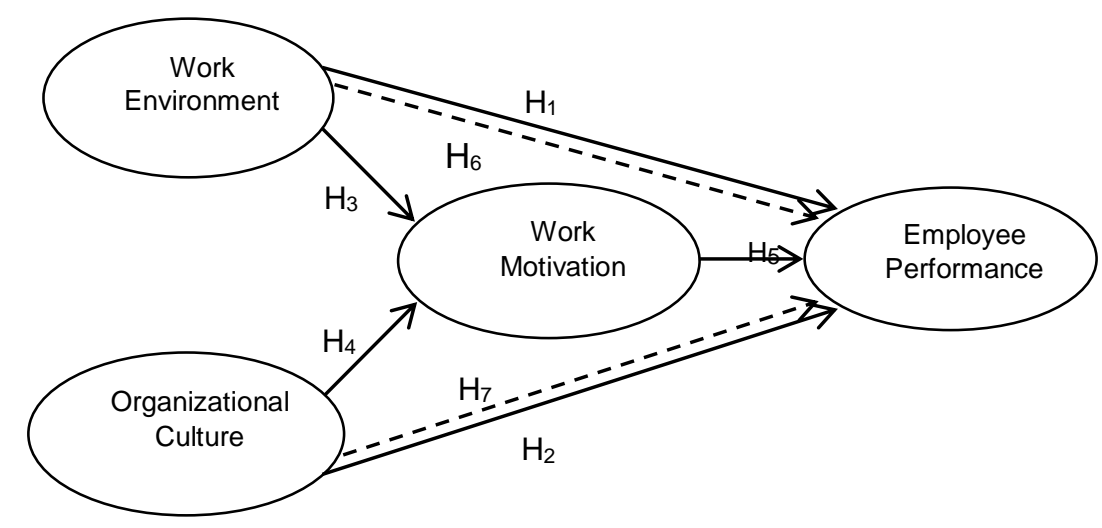

Figure 1. Research Conceptual Model

\section{METHODS}

The approach in this reseacrh uses a quantitative approach with a survey method. The purpose of this reseacrh is to find out and analyze the relationship between variables through testing the hypothesis so that it is also called explanatory research. The population of this research is the operational field employees of PT Bank Pembangunan Daerah Provinsi Jawa Timur Tbk Sidoarjo Branch. The method used in this reseacrh is a census or saturated sample, that is, all members of the population are sampled (Sugiyono, 2015). The total population is 134 employees, so the respondents of this reseacrh amounted to 134 employees. The conditions of the respondents in this reseacrh are with a minimum work period of 1 year.

The research instrument in this research tested the feasibility of 30 respondents outside the study sample using validity and reliability tests with the help of the SPSS program. If the instrument is valid and reliable, it will be distributed directly to the respondent. The data obtained in this study were then carried out statistical analysis using Partial Least Square (PLS) with the help of SmartPLS 3.0 software. Model evaluation in PLS analysis is done in two ways, namely the measurement model (outer model) and structural model (inner model). Outer model is a measurement model to show the specification of the relationship between variables and indicators. While the structural model (inner model) shows the specification of the relationship between hidden or latent variables, namely between exogenous variables with endogenous variables (Ghozali dan Latan, 2012). 


\section{RESULTS AND DISCUSSION}

\section{Testing of Research Instruments (Pilot Test)}

Table 2 shows all statement items for the variables in this research having a value of $r$ hitung $>r$ tabel (0.30) (Sugiyono, 2015), so that statement items have been valid or can clearly describe the variables studied. All research variables also have Cronbach Alpha coefficients greater than 0.6 (Arikunto, 2010), so the instrument of this research has been reliable, and statement items are worthy of being used in this study.

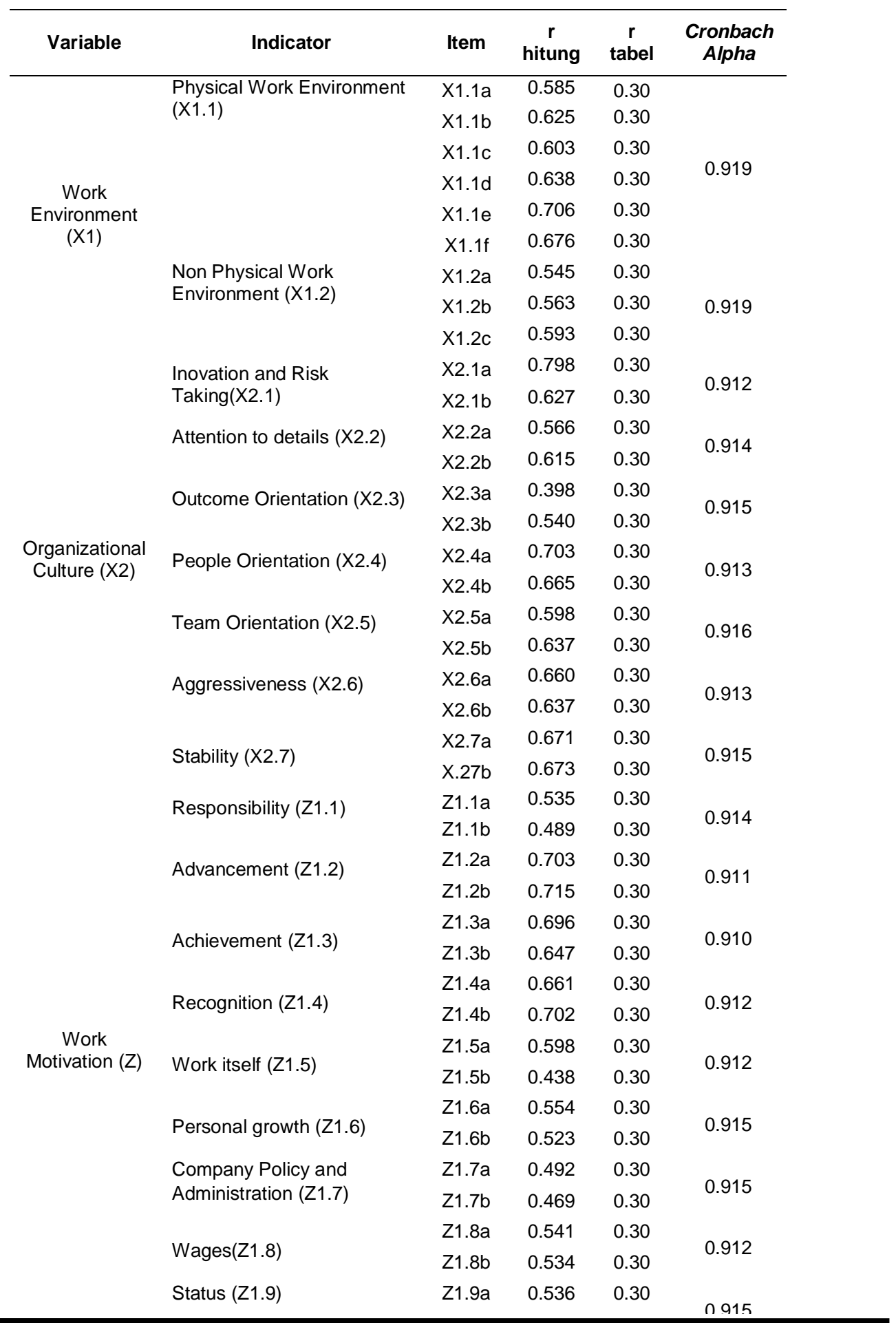

60 Management and Economics Journal (MEC-J)

Vol 3 (1) April 2019 
Adiwiratna Briandana Ganefanto Rachmat, et al.

\begin{tabular}{|c|c|c|c|c|c|}
\hline Variable & Indicator & Item & $\stackrel{\text { r }}{\text { hitung }}$ & $\stackrel{r}{\text { tabel }}$ & $\begin{array}{c}\text { Cronbach } \\
\text { Alpha }\end{array}$ \\
\hline & \multirow[b]{3}{*}{ Job Security (Z1.10 } & Z1.9b & 0.515 & 0.30 & \multirow{2}{*}{0.912} \\
\hline & & Z1.10a & 0.469 & 0.30 & \\
\hline & & Z1.10b & 0.465 & 0.30 & 0.915 \\
\hline & \multirow{2}{*}{ Working Conditions (Z1.11) } & Z1.11a & 0.423 & 0.30 & \multirow{2}{*}{0.914} \\
\hline & & $\mathrm{Z1.11b}$ & 0.605 & 0.30 & \\
\hline & \multirow{2}{*}{$\begin{array}{l}\text { Interpersonal relationships } \\
\text { with colleagues }(Z 1.12)\end{array}$} & $\mathrm{Z1.12a}$ & 0.632 & 0.30 & \multirow{2}{*}{0.911} \\
\hline & & $\mathrm{Z1.12b}$ & 0.547 & 0.30 & \\
\hline & \multirow{2}{*}{$\begin{array}{l}\text { Interpersonal relationships } \\
\text { with supervisorsr (Z1.13) }\end{array}$} & $\mathrm{Z1.13a}$ & 0.559 & 0.30 & \multirow{2}{*}{0.910} \\
\hline & & $\mathrm{Z1.13b}$ & 0.617 & 0.30 & \\
\hline & \multirow{2}{*}{$\begin{array}{l}\text { Quality of supervision } \\
\text { (Z1.14 }\end{array}$} & $\mathrm{Z1.14a}$ & 0.559 & 0.30 & \multirow{2}{*}{0.912} \\
\hline & & Z1.14b & 0.617 & 0.30 & \\
\hline & \multirow{2}{*}{ Quality (Y1.1) } & Y1.1a & 0.802 & 0.30 & \multirow{2}{*}{0.912} \\
\hline & & Y1.1b & 0.815 & 0.30 & \\
\hline \multirow{4}{*}{$\begin{array}{c}\text { Employee } \\
\text { Performance } \\
\text { (Y) }\end{array}$} & \multirow{2}{*}{ Quantity (Y1.2) } & $\mathrm{Y} 1.2 \mathrm{a}$ & 0.736 & 0.30 & \multirow{2}{*}{0.913} \\
\hline & & $\mathrm{Y} 1.2 \mathrm{~b}$ & 0.682 & 0.30 & \\
\hline & \multirow[t]{2}{*}{ Attitude (Y1.3) } & Y1.3a & 0.587 & 0.30 & \multirow{2}{*}{0.912} \\
\hline & & $\mathrm{Y} 1.3 \mathrm{~b}$ & 0.865 & 0.30 & \\
\hline
\end{tabular}

\section{Data Analysis Results}

This research uses the SEM method based on Partial Least Square (PLS). The PLS software used is SMART PLS version 3.0. In the PLS application there are two stages, namely assessing the outer model and then evaluating the inner model or structural model.

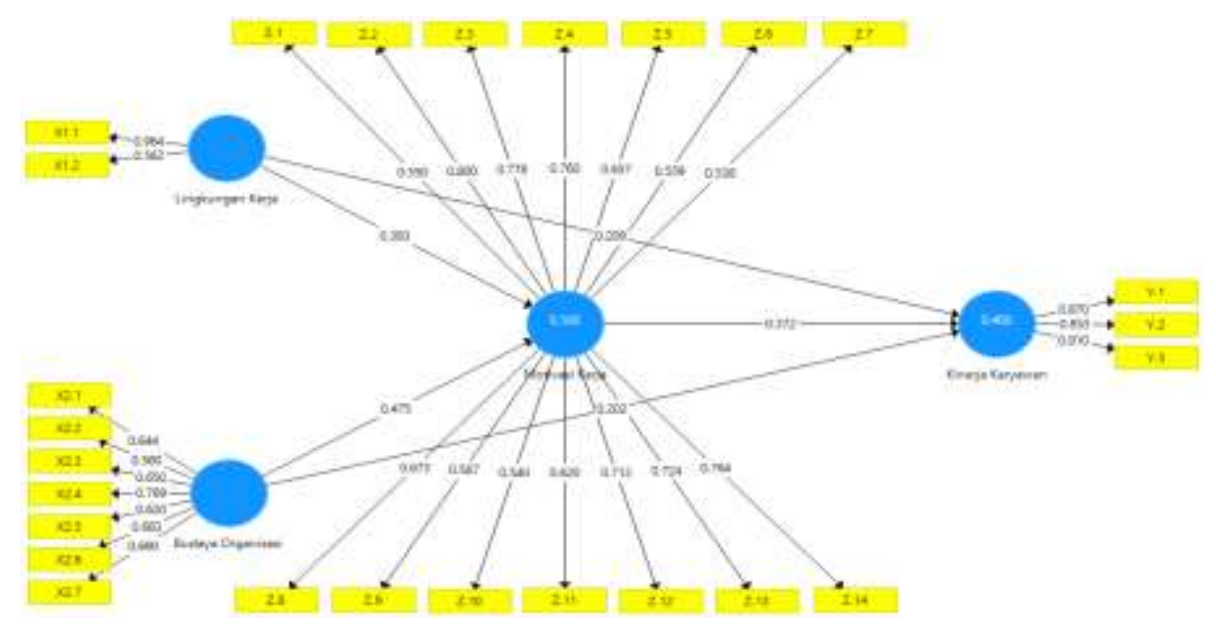

Figure 2. Outer Model Testing Results

Based on Figure 2, the outer loading value of each item is more than 0.50 so that the item can be valid, and the reliability test results show that the composite reliability value of each research variable is more than 0.70 and cronbach's alpha is more than 0.60 so that the instrument used in research is reliable.

Table 3. Results of Testing Direct and Indirect effect Hypotheses

\begin{tabular}{|c|c|c|c|c|}
\hline Hyphotesis & Relationship & Path Coefficient & $t-$ & Information \\
\hline
\end{tabular}


Effect of Work Environment and Organizational Culture...

\begin{tabular}{|c|c|c|c|c|c|}
\hline & & $\begin{array}{l}\text { Direct } \\
\text { Effect }\end{array}$ & $\begin{array}{c}\text { Indirect } \\
\text { Effect }\end{array}$ & statistics & \\
\hline $\mathrm{H1}$ & $\mathrm{X} 1->\mathrm{Y}$ & 0.209 & & 2.351 & Significant \\
\hline $\mathrm{H} 2$ & $X 2->Y$ & 0.202 & & 2.141 & Significant \\
\hline H3 & $X 1->Z$ & 0.393 & & 5.560 & Significant \\
\hline $\mathrm{H} 4$ & X2 -> Z & 0.475 & & 7.186 & Significant \\
\hline H5 & $Z->Y$ & 0.372 & & 4.229 & Significant \\
\hline H6 & $X 1->Z \rightarrow Y$ & & 0.146 & 3.403 & Significant \\
\hline $\mathrm{H} 7$ & $X 2->Z \rightarrow Y$ & & 0.177 & 3.571 & Significant \\
\hline
\end{tabular}

Based on table 3 shows that the work environment has a significant and positive influence on employee performance with a t-statistic value greater than t-table (2.351> 1.96), so $H_{1}$ accepted. Organizational culture was found to have a significant and positive effect on employee performance with a t-statistic value greater than t-table $(2.141<1.96)$, so $\mathbf{H}_{2}$ accepted. Hypothesis testing also shows that the work environment has a significant and positive influence on work motivation with a t-statistic value greater than t-table (5.560> 1.96), so that $\mathbf{H}_{3}$ accepted. Organizational culture was found to have a significant and positive influence on work motivation with a t-statistic value greater than t-table (7.186>1.96), so that $\mathbf{H}_{4}$ accepted. Work motivation is found to have a significant and positive effect on employee performance with a t-statistic value greater than t-table (4.229>1.96), so that $H_{5}$ accepted.

Based on table 3 also shows that work motivation can be found to mediate the relationship of the influence of the work environment on employee performance, because it has a t-statistic value greater than t-table $(3,403>1.96)$, so $\mathbf{H}_{6}$ accepted. Work motivation is also found to be mediating the relationship between the influence of organizational culture on employee performance, because it has a t-statistic value greater than t-table (3.571>1.96), so that $\mathbf{H}_{7}$ accepted. Based on the results of research on the indirect effect of work motivation on the relationship of the work environment to the performance of employees has a partial mediation role. Furthermore, it is also found that the motivation of work on the relationship of organizational culture to employee performance has a partial mediation role.

\section{DISCUSSION}

The results of the research show that the work environment has a significant influence on employee performance. This can be interpreted that employee performance can increase due to the role of the work environment. Employees feel that their performance can increase because of the role of the work environment that is built and created by both companies and employees. The results of this research are also in line with previous reseacrh by Malik, et al. (2011), Nguyen, et al. (2014), Jayaweera (2015), Nurjanah, et al. (2014) which states that the work environment has a role in improving employee performance. this can be seen from the results of their research where the work environment has a significant effect on employee performance. The results of this research indicate that organizational culture has a significant effect on employee performance. This means that employee performance can increase because of the role of organizational culture. This is also supported by the annual report of PT Bank Pembangunan Daerah Provinsi Jawa Timur Tbk in 2017, the corporate culture has a big role in creating smooth operations and productivity of the company, namely changing attitudes, and also the behavior of existing HR in order to increase work productivity. Employees feel that by applying the corporate culture of PT Bank Pembangungan Daerah Provinsi Jawa Timur Tbk will have a positive impact on their performance. Corporate culture for employees in the operational fields of PT Bank Pembangunan

62 Management and Economics Journal (MEC-J)

Vol 3 (1) April 2019 
Daerah Provinsi Jawa Timur Tbk Sidoarjo Branch is as useful values and guidelines when working. The results of this research are also in line with previous research by Murugan (2009), Shahzad (2014), Wahyuni (2015), Endrias (2014) which states that organizational culture has a role in improving employee performance. this can be seen from the results of their research where organizational culture has a significant effect on employee performance.

The results of the research indicate that the work environment has a significant influence on employee motivation at PT Bank Pembangunan Daerah Provinsi Jawa Timur Sidoarjo Branch. This can be interpreted that in practice the work environment has a role on employee motivation. The better the work environment built by the company, the higher the motivation shown by the employee at work. Based on this, it can be seen how much benefit can be given from the aspect of the work environment one of which is able to increase employee motivation at work. This is in line with the opinion expressed by Ishak and Tanjung, quoted by Riansari (2013) regarding the benefits of the work environment is to create work passion, so that productivity and work performance increase. Meanwhile, the benefits obtained from working with motivated people are work completed according to the correct standards and on a specified time scale. The results of this research are also in accorandce with previous studies conducted by Martin (1996), Noor (2014), and Sanny, et al. (2012) who found that the work environment can influence work motivation. The results showed that organizational culture had a significant effect on work motivation. This indicates that organizational culture can increase employee motivation. The employee of PT Bank Pembangunan Daerah Provinsi Jawa Timur Tbk Sidoarjo Branch feels that implementing a corporate culture in work can increase work enthusiasm so that it can provide good performance for the company. The results of this research are also in line with previous research by Taslim (2011), Koesmono (2005), Ernanto, et al. (2015) which states that organizational culture has a role in increasing employee motivation. The role of organizational culture can also be seen how employees are able to apply and understand the values of the company so that it can motivate employees not only to work passionately but also to motivate employees in terms of morale and discipline in work.

The results showed that motivation had a significant effect on employee performance. this can be interpreted that the higher the motivation received by the employee, the better the performance shown for the company. This is felt by the Employees of PT Bank Pembangunan Daerah Provinsi Jawa Timur Tbk Sidoarjo Branch where employees feel the motivation given by the company through various ways has a positive impact on employee performance. The results of this research are also in line with previous empirical studies conducted by Shafighi, et al. (2013), Zameer (2014), and Supartini (2017) who found results that work motivation has a significant influence on employee performance.

Based on the results of data analysis that has been done, this research found that work motivation has a mediating role in the relationship of the influence of the work environment on employee performance. In this research it was found that the work environment is able to influence employee performance directly, but when mediated by work motivation, the work environment can still affect employee performance so that the role of mediating work motivation is partial mediation. It can be concluded that the role of the work environment can provide a positive impact on employee performance and also have a positive impact on work motivation. Furthermore, this research also found that work motivation has a mediating role in the relationship of the effect of 
organizational culture on employee performance. In this research it was found that organizational culture is able to influence employee performance directly, but when mediated by work motivation, organizational culture can still influence employee performance so that the role of mediating work motivation is partial mediation.

\section{CONCLUSIONS}

The work environment at PT Bank Pembangunan Daerah Provinsi Jawa Timur Tbk Sidoarjo Branch is able to play a role in improving employee performance. The existence of this role explains that employee performance can increase due to a supportive work environment. The importance of the role of the work environment so that the PT Bank Pembangunan Daerah Provinsi Jawa Timur Tbk Sidoarjo Branch strives to build and create a good work environment for employees so as to improve employee performance.

Organizational culture is able to improve the performance of operational field employees of PT Bank Pembangunan Daerah Provinsi Jawa Timur Tbk Sidoarjo Branch. This can be seen by the ability of employees to apply company values while working. That is, the operational field employees of PT Bank Pembangunan Daerah Provinsi Jawa Timur Tbk Sidoarjo Branch are able to apply the company's values well so that they are able to demonstrate the performance of employees through the quality of work and good work attitudes.

The work environment that has been built by PT Bank Pembangunan Daerah Provinsi Jawa Timur Tbk Sidoarjo Branch is able to play a role in increasing employee motivation. This can be interpreted that employees feel that a well-built work environment will increase employee motivation.

Organizational culture is able to have a positive impact on employee motivation. This can be indicated by the operational field employees of PT Bank Pembangunan Daerah Provinsi Jawa Timur Tbk Sidoarjo Branch is able to apply company values well so that the work motivation of employees in terms of behavior and ethics while working also increases.

Work motivation of operational field employees of PT Bank Pembangunan Daerah Provinsi Jawa Timur Tbk Sidoarjo Branch is able to improve employee performance. That is, the higher the work motivation that is felt by the employee then encourages employees to improve performance.

Work motivation successfully gives a role in the relationship of work environment and employee performance. This success is due to the achievement of employee work motivation so that the work environment can improve employee performance. That is, that work motivation has a role in bridging the relationship between the work environment and employee performance.

Work motivation is able to mediate the relationship between organizational culture and employee performance. These results can be explained that with employees able to apply company values well it will provide positive benefits to performance so employees will be motivated to improve their performance.

\section{REFERENCES}

64 Management and Economics Journal (MEC-J)

Vol 3 (1) April 2019 
Ardiaz, Fian, Achmad Sudiro, and Noermijati. 2017. Pengaruh Motivasi Kerja And Gaya Kepemimpinan Transformasional Terhadap Kinerja Karyawan Dimediasi Kepuasan Kerja (Studi pada PT BANK RAKYAT INDONESIA (Persero) Tbk Kantor Cabang Malang Marthadinata). Jurnal Bisnis and Manajemen Vol. 4. No. 1. P 64-73

Arikunto, S. 2010. Prosedur penelitian : Suatu Pendekatan Praktik. (Edisi Revisi). Jakarta : Rineka Cipta

Bambang, Kusriyanto. 1991. Meningkatkan Produktvitas Karyawan. Jakarta: Pustaka Binaman Pressindo.

Carson,K. P., Cardy, R. L., and Dobbins, G. H. 1991. Performance appraisal as effectivemanagement or deadly management disease: two empirical investigations. Group and Organization Studies, 16(2), 143-159.

Endrias, Win Susilo Hari, 2014. Pengaruh Gaya Kepemimpinan Dan Budaya Organisasi Terhadap Kinerja Pegawai Melalui Kepuasan Kerja Sebagai Variabel Intervening (Studi Kasus Pada Kantor Pelayanan Pajak Pratama Ruteng). Jurnal MIX, volume IV, no.1, P. 70-82

Ernanto, Bambang, Lukman M. Baga, and Euis Sunarti. 2015. Pengaruh Penerapan Budaya Perusahaan Terhadap Motivasi Kerja and Kinerja Karyawan di PT. Rekayasa Industri. Jurnal Aplikasi Bisnis and Manajemen (JABM) Vol. 1 No. 1, P. 1-10

Fahmi, Irham. 2013. Perilaku Organisasi Teori Aplikasi and Kasus. Bandung: Alfabeta

Ghozali, I, and Latan, H. 2012. Partial Least Squares: Konsep, Teknik, and Aplikasi Menggunakan Program SmartPLS 2.0 M3. Baand Penerbit Universitas Diponegoro. Semarang.

Ilgen, D. R., and Janet. L Favero. 1985. Limits in generalization from psychological research to performance appraisal processes. Academy of Management Review, 10(2), 311-321.

Jayaweera, Thushel. 2015. Impact of Work Environmental Factors on Job Performance, Mediating Role of Work Motivation: A Study of Hotel Sector in England. International Journal of Business and Management, Vol. 10, No. 3, P. 271-277

Koesmono, H. Teman. 2005. Pengaruh Budaya Organisasi Terhadap Motivasi and Kepuasan Kerja Serta Kinerja Karyawan Pada Sub Sektor Industri Pengolahan Kayu Skala Menengah Di Jawa Timur. Jurnal Manajemen and Kewirausahaan, Vol. 7, No. 2. P. 171-188.

Kolter, J. P, and J. L. Heskett.1992. Coporate Culture and Performance. Free, Pres:New York

Mahmudi. 2010. Manajemen Kinerja Sektor Publik. Edisi Keuda. Sekolah Tinggi IImu Manajemen YKPN. Yogyakarta

Malik, M. Imran., Ashfaq Ahmad., Soloman Fernado Gomez., and Mumtaz Ali. 2011. A Study of Work Environment and Employees' Performance in Pakistan. African Journal of Business Management Vol. 5(34), pp. 13227-13232.

Martin, Gregg D. 1996. The Effects Of Employee Characteristics And Work Environment Factors On Learning During Training And On Pretraining Motivation To Learn. Dissertation. Columbia: University of Missouri.

Murugan, M. Sakthivel. 2009. A Study on Organizational Culture and Its Impact on the Performance of IT Employees in Chennai. The IUP Journal of Management Research, Vol. VIII, No. 5 P. P 6-16

Nguyen, Phong D., Chuong X. Dang, and Lam D. Nguyen. 2014 Would Better Earning, Work Environment, and Promotion Opportunities Increase Employee Performance? An Investigation in State and Other Sectors in Vietnam. Public Organiz Rev (2015), P.565-579

Noermijati, 2013. Kajian tentang Aktualisasi Teori Hezberg, Kepuasan Kerja, and Kinerja Spiritual Manajer Operasional. Malang: UB Press 
Noor, Asmirin. 2014. Pengaruh Lingkungan Kerja Terhadap Motivasi Kerja And Kinerja Pegawai Di Satuan Kerja Unit Pelaksana Penimbangan (Jembatan Timbang) Dinas Perhubungan And LLAJ Jawa Timur. Media Mahardhika Vol. 12 No. 2 P. 137-162

Nurjanah, Siti, and Eni Ariyanto, 2014. Pengaruh Motivasi, Pelatihan, And Lingkungan Kerja Terhadap Kinerja Karyawan Outsourcing Pada PT BRI, Tbk Kantor. Jurnal Telaah bisnis, volume 15, P. 105-116

Nurdin, Sahidillah, and Acep Rohendi. 2016. Gaya Kepemimpinan Transformasional, Budaya Organisasi, And Kinerja Karyawan Dengan Mediasi Komitmen Organisasi (studi pada Lembaga Penyiaran Publik (LPP) TVRI Jawa Tengah). Ecodomica, Volume IV, no.1, P. 86-100

Prabowo, Thoni Setyo, Noermijati, Dodi Wirawan Irawanto. 2018. The Influence of Transformational Leadership And Work Motivation On Employee Performance Mediated By Job Satisfaction. Journal Of Applied Management Vol. 16 No. 1. P. 171-178

Sanny, Lim, Selby Kristanti. 2012. Pengaruh Lingkungan Kerja And Job Insecurity Terhadap Motivasi Kerja And Dampaknya Pada Kinerja Karyawan Outsourcing Mall Lippo Cikarang. BINUS BUSINESS REVIEW Vol. 3 No. 1 Mei 2012: 61-69

Shafighi, Ali Akbar, and Maryam Azar. 2013. The Effect of Work Motivation on Employee's Job Performance (Case Study: Employee's of Ishafahan Islamic Revolution Housing Foundation). International Journal of Academic Research in Business and Social Sciences, Vol. 3, No. 9 P. 432-445

Shahzad, Fakhar. 2014. Impact of organizational culture on employees' job performance : An empirical study of software houses in Pakistan. Journal of Commerce and Management, Vol. 24 Iss 3 pp. $219-227$

Sedarmayanti, 2001. Tata Kerja and Produktivitas Kerja. Bandung: Mandar Maju.

Riansari, Titi. 2013. Pengaruh Kompensasi and Lingkungan Kerja Terhadap Kepuasan Kerja and Kinerja Karyawan (Studi Pada PT. Bank Tabungan Pensiunan Nasional Cabang Malang). Jurnal Aplikasi Manajemen, Volume 09, Nomor 4, P. 811-820

Robbins, Stephen P. 2002. Prinsip-Prinsip Perilaku Organisasi. Edisi Kelima (Terjemahan). Jakarta: Penerbit Erlangga.

Robbins, Stephen P. 2006. Perilaku Organisasi, Jilid I. PT. Prenhallindo, Alih bahasa: Hadyana Pujaatmaka, Jakarta

Robbins, Stephen, Timothy A Judge. 2012. Essentials of Organizational Behaviour. 12th Edition. New Jersey: Pearson Education Inc

Sugiyono. 2015. Metode Penelitian Kuntitatif, Kualitatif, and RandD. Alfabeta. Bandung.

Supartini, Tini. 2017. Pengaruh Kepemimpinan Transformasional, Motivasi Kerja, Kompetensi, Terhadap Kinerja Karyawan Di PT. Bank Muamalat Indonesia, Tbk Cabang Bandung. Bisnis and Iptek Vol.10, No. 1, April 2017, 65-80

Taslim, Mohammad. 2011. Organisation Culture And Employee Motivation: An Emperical Study On Impact Of Organisation Culture On Employee Extrinsic and Intrinsic Motivation At SBI. Summer Internship Society Volume III Issue-1.

Wahyuni, Evi. 2015. Pengaruh Budaya Organisasi And Caya Kepemimpinan Terhadap Kinerja Pegawai Bagian Keuangan Organisasi Sektor Publik Dengan Motivasi Kerja Sebagai Variabel Intervening (Studi Kasus Pada PegawaiPemerintahKotaTasikmalaya). Jurnal Nominal / Volume Iv Nomor 1 / Tahun 2015, P. 96-112

Zameer, H., Ali, S., Nisar, W., and Amir, M. 2014. The Impact Of The Motivation On The Employee's Performance in Beverage Industry of Pakistan. Internataional Journal of Academic Research in Accounting, Finance and Mangement Science Vol. 4. No. 1. P. 293-298. 